\title{
IMPLEMENTASI PENDEKATAN KONTEKSTUAL PADA MODEL PEMBELAJARAN BERBASIS MASALAH BERDASARKAN LANGKAH-LANGKAH POLYA
}

\author{
Nur Eva Zakiah1, Yoni Sunaryo², Asep Amam ${ }^{3}$ \\ 1,2,3 Universias Galuh, Jl. R. E. Martadinata No.150, Ciamis, Indonesia \\ email: nureva.math@gmail.com
}

\begin{abstract}
This study aims to describe the design of contextual approaches using problem based learning models based on Polya's steps. This article is a study of literature studies. The results showed that the design of learning with a contextual approach using the problem-based learning model based on Polya's steps can be used as an innovation in learning in accordance with current curriculum demands, namely: (1) orienting students to the problem; (2) organizing learning activities; (3) guiding independent and group investigations based on Polya's problem solving steps, including: (a) understanding the problem; (b) draw up a plan; (c) carry out the plan; and (d) looking back; (4) develops and presents the work; and (5) analyzing and evaluating the problem solving process. Giving non-routin mathematical problems presented in the form of contextual math problems, as well as open or structured problems that are applied to problem based learning are potentially used in learning as an effort to improve the quality of education.
\end{abstract}

Keywords: Polya problem solving steps, contextual approach, problem based learning

\begin{abstract}
ABSTRAK
Penelitian ini bertujuan untuk mendeskripsikan rancangan pendekatan kontekstual pada model pembelajaran berbasis masalah berdasarkan langkah-langkah Polya. Artikel ini merupakan kajian studi literatur. Hasil kajian menunjukkan bahwa desain pembelajaran menggunakan pendekatan kontekstual pada model pembelajaran berbasis masalah berdasarkan langkah-langkah Polya dapat dijadikan sebagai inovasi dalam pembelajaran yang sesuai dengan tuntutan kurikulum saat ini, yaitu: (1) mengorientasikan siswa pada masalah; (2) mengorganisasikan kegiatan pembelajaran; (3) membimbing invesitigasi mandiri dan kelompok berdasarkan langkah-langkah pemecahan masalah Polya, diantaranya: (a) memahami masalah; (b) menyusun rencana; (c) melaksanakan rencana; dan (d) mengecek kembali; (4) melakukan pengembangan dan mempresentasikan hasil karya; dan (5) melakukan analisis dan evaluasi terhadap proses pemecahan masalah. Pemberian masalah matematis non-routin yang disajikan dalam bentuk soal matematika kontekstual, maupun masalah terbuka atau terstruktur yang diterapkan pada pembelajaran berbasis masalah potensial digunakan dalam pembelajaran sebagai upaya untuk meningkatkan kualitas pendidikan.
\end{abstract}

Kata Kunci: Langkah-langkah pemecahan masalah Polya, pendekatan kontekstual, pembelajaran berbasis masalah

Dikirim: 27 September 2019; Diterima: 28 September 2019; Dipublikasikan: 30 September 2019

Cara sitasi: Zakiah, N. E., Sunaryo, Y., \& Amam, A. (2019). Implementasi pendekatan kontekstual pada model pembelajaran berbasis masalah berdasarkan langkah-langkah polya. Teorema: Teori dan Riset Matematika, $4(2), 111-120$. 


\section{PENDAHULUAN}

Pendidikan memiliki peran strategis dalam membentuk karakter manusia yang memiliki kualitas unggul. Undang-Undang Sistem Pendidikan Nasional, mengamanatkan bahwa pendidikan nasional memiliki fungsi untuk mengembangkan keterampilan/kemampuan warga negara sehingga tercipta peradaban bangsa yang bermartabat sebagai upaya mencerdaskan kehidupan bangsa. Karakter manusia Indonesia yang diharapkan menurut undang-undang tersebut adalah manusia yang memiliki keimanan dan ketakwaan, kepribadian mulia, sehat jasmani dan rohani, berwawasan luas, kreativitas, kemandirian, serta memiliki tanggung jawab. Usaha yang dapat dilakukan dalam pembentukan karakter yaitu melalui peningkatan kualitas pendidikan.

Peran para pendidik atau guru dalam rangka meningkatkan kualitas pendidikan, diantaranya merancang pembelajaran di dalam kelas agar siswa mendapatkan pembelajaran yang bermakna dan dirancang melalui suatu kurikulum pendidikan. Dalam hal ini pemerintah telah menetapkan suatu standar kompetensi lulusan yang harus dimiliki oleh peserta didik yang telah menyelesaikan pendidikannya. Kompetensi tersebut disesuaikan dengan kebutuhan abad XXI, diantara kompetensi yang diperlukan tersebut yaitu mencakup pengetahuan, sikap dan keterampilan. Penjelasan tentang masing-masing kualifikasi tersebut dijelaskan dalam Permendikbud (2016a) bahwa kemampuan siswa pada dimensi sikap mencerminkan sikap: (1) memiliki keimanan dan ketakwaan terhadap Tuhan YME; (2) berkarakter, jujur, dan peduli; (3) bertanggungjawab; (4) menjadi pembelajar seumur hidup, dan (5) sehat jasmani dan rohani.

Pada dimensi pengetahuan, siswa memiliki pengetahuan meliputi faktual, konseptual, prosedural dan metakognitif berkenaan dengan: (1) ilmu pengetahuan; (2) teknologi; (3) seni; (4) budaya, dan (5) humaniora. Selain itu siswa mampu mengaitkan pengetahuan yang sesuai dengan pengalaman pada diri sendiri, lingkungan disekitar termasuk lingkungan keluarga, lingkungan sekolah dan lingkungan alam. Sedangkan pada dimensi keterampilan, siswa memiliki keterampilan untuk melakukan pemikiran dan tindakan, diantaranya: (1) kreatif; (2) produktif; (3) kritis; (4) mandiri; (5) mampu berkolaborasi, dan (6) mampu berkomunikasi. Kemampuan ini dapat diperoleh siswa melalui pembelajaran matematika.

Tujuan pembelajaran matematika tingkat pendidikan menengah atas menurut Permendikbud (2016b) menyatakan bahwa diantaranya agar para siswa memiliki kompetensi: (1) sikap logis, kritis, kreatif, analitis, cermat dan teliti, memiliki tanggung jawab, responsif, dan tidak mudah menyerah dalam memecahkan suatu masalah; (2) rasa ingin tahu, percaya diri, semangat untuk terus belajar, berpikir reflektif dan memiliki minat terhadap matematika; (3) rasa percaya terhadap kegunaan matematika, serta sikap kritis yang dihasilkan dari proses interaksi dan pengalaman belajar; (4) sikap terbuka, objektif, dan menghargai terhadap hasil karya teman yang dihasilkan dalam interaksi kelompok ataupun kegiatan dalam kehidupan sehari-hari; dan (5) kemampuan untuk mengkomunikasikan gagasan matematika dengan jelas dan efektif.

Berdasarkan standar isi tersebut, perlu adanya inovasi pembelajaran yang dilakukan guru di dalam kelas untuk mengoptimalkan kegiatan pembelajaran agar bermakna bagi siswa, menyenangkan, serta pembelajaran dapat mendorong siswa untuk mengkonstruk dan mengembangkan pengetahuan yang telah dimiliki sebelumnya. Dalam merancang pelaksanaan pembelajaran pada tingkat satuan pendidikan diperlukan beberapa kriteria yang berpatokan pada standar proses menurut Permendikbud (2016c), meliputi aspek perencanaan kegiatan pembelajaran, pelaksanaan kegiatan pembelajaran, penilaian hasil pembelajaran, dan pengawasan proses pembelajaran. Oleh karena itu beberapa kriteria yang dapat diaplikasikan dalam merancang proses pembelajaran, diantaranya (a) adanya interaksi antara guru, siswa, dan sumber belajar; (b) saling menginspirasi antara guru dan siswa; (c) aktivitas pembelajaran yang menyenangkan dan menantang; (c) memotivasi siswa untuk berpartisipasi aktif; (d) tersedianya kesempatan bagi siswa untuk menghasilkan karya dan kreativitas; dan (e) mengembangkan kemandirian sesuai dengan minat, bakat serta perkembangan mental dan fisik siswa. Dengan demikian dalam merancang 
pembelajaran, guru harus dapat menjadi perancang pembelajaran yang baik agar tujuan pembelajaran tercapai secara efektif dan efisien.

Pembelajaran yang efektif dapat diwujudkan, salah satunya melalui perancangan rencana pembelajaran yang dituangkan dalam rencana pelaksanaan pembelajaran (RPP) dengan pemilihan model pembelajaran. Dalam hal ini, diperlukan kemampuan guru untuk memilih dan menggunakan model pembelajaran dengan memperhatikan karakteristik materi pelajaran, ketersediaan media pembelajaran, perkembangan mental dan fisik siswa.

Pembelajaran yang mengkoneksikan antara materi pelajaran dengan konteks kehidupan sehari-hari dapat memberikan siswa banyak pengalaman dalam menafsirkan masalah dan mungkin pula menumbuhkan ide-ide yang bervariasi dalam menyelesaikan permasalahan (Silver, 1997). Proses pembelajaran seperti ini akan membiasakan siswa untuk merencanakan kegiatan pemecahan masalah, menyelesaikan/melakukan perhitungan, melakukan monitoring terhadap proses pemecahan masalah, dan mengevaluasi terhadap hasil yang telah diperoleh.

Pendekatan kontekstual merupakan pendekatan pembelajaran yang menghubungkan materi pembelajaran dengan konteks kehidupan sehari-hari baik dalam lingkungan keluarga, masyarakat, alam sekitar dan dunia kerja, sehingga siswa mampu memiliki kemampuan untuk membuat koneksi antara pengetahuan yang diperolehnya dengan aplikasinya dalam kehidupan sehari-hari (Jumadi, 2003). Oleh karena itu, siswa perlu memahami tentang arti belajar, manfaat belajar, dan bagaimana mencapainya. Sehingga siswa akan mengerti tentang kegunaan materi pembelajaran dengan kehidupannya.

Berbagai penelitian yang telah berhasil menggunakan pendekatan kontekstual, diantaranya Zakiah (2017a) mengungkapkan bahwa penggunaan masalah kontekstual dalam kehidupan seharihari dapat membantu siswa dalam memahami materi. Hasil penelitian Zakiah dan Sunaryo (2017) melaporkan bahwa pendekatan kontekstual dengan memperhatikan gaya kognitif siswa mampu meningkatkan kemampuan metakogitif dan self awareness siswa. Selanjutnya hasil penelitian Sunaryo dan Fatimah (2018) bahwa penerapan pembelajaran menggunakan pendekatan kontekstual melalui model pembelajaran scaffolding dapat meningkatkan kemampuan matematis siswa yaitu berpikir kritis matematik siswa.

Depdiknas (2002) mengemukakan bahwa terdapat tujuh komponen utama dalam pendekatan kontekstual, yaitu: (a) konstruktivisme; (b) bertanya; (c) menemukan; (d) masyarakat belajar; (e) pemodelan; (f) refleksi; dan (g) penilaian sebenarnya. Selanjutnya Jumadi (2003) menyatakan bahwa beberapa model pembelajaran yang merupakan aplikasi pendekatan kontekstual antara lain: (a) model pembelajaran langsung (direct instruction); (b) pembelajaran kooperatif (cooperative learning); dan (c) pembelajaran berbasis masalah (problem based-learning).

Pembelajaran berbasis masalah (PBM) menggunakan masalah kontekstual dalam proses pembelajarannya sehingga mampu memotivasi siswa untuk belajar. Guru yang menggunakan pembelajaran berbasis masalah, merancang aktivitas belajar siswa bekerja dalam kelompok untuk memecahkan masalah yang diberikan oleh guru berupa permasalahan dunia nyata (real world). Dalam pembelajaran berbasis masalah, guru mempresentasikan situasi masalah pada siswa dan meminta agar siswa melakukan investigasi dan menemukan solusi sendiri (Arends, 2012). Guru juga perlu merancang tugas dari masalah autentik dan ill-structure, serta memberikan kebebasan pada siswa untuk memecahkan masalah, dan memberikan bimbingan (So, H.J.\& Kim, B, 2009). Penelitian yang dilakukan Fatimah \& Zakiah (2018) menganalisis pemberian masalah pada konteks pemasaran dapat menuntun siswa sukses mencapai penyelesaian yang masuk akal. Oleh karenanya, permasalahan yang sesuai untuk mengembangkan serta meningkatkan kemampuan berpikir matematis siswa adalah berupa masalah-masalah kontekstual nonrutin (contextual problems). Soal pemecahan masalah ini bisa dirancang dalam bentuk masalah terbuka ataupun masalah terstruktur.

Arends (2012) menjelaskan bahwa terdapat lima tahapan dalam melaksanakan pembelajaran berbasis masalah yang dijelaskan pada tabel berikut. 
Tabel 1. Langkah-langkah model pembelajaran berbasis masalah

\begin{tabular}{|c|c|c|}
\hline Fase & Kegiatan Pembelajaran & Deskripsi \\
\hline 1 & Mengorientasikan siswa pada masalah & $\begin{array}{l}\text { Guru menyampaikan tujuan pembelajaran yang } \\
\text { akan diperoleh siswa, melakukan apersepsi } \\
\text { kepada siswa melalui pengecekan materi } \\
\text { sebelumnya dengan tanya jawab, dan } \\
\text { pemberian motivasi untuk semangat belajar }\end{array}$ \\
\hline 2 & Mengorganisasikan kegiatan pembelajaran & $\begin{array}{l}\text { Guru mengorganisasi siswa belajar dalam } \\
\text { kelompok }\end{array}$ \\
\hline 3 & $\begin{array}{l}\text { Membimbing invesitigasi mandiri dan } \\
\text { kelompok }\end{array}$ & $\begin{array}{l}\text { Guru mendorong siswa untuk mengumpulkan } \\
\text { data dan melakukan percobaan }\end{array}$ \\
\hline 4 & $\begin{array}{l}\text { Melakukan pengembangan dan } \\
\text { mempresentasikan hasil karya }\end{array}$ & $\begin{array}{l}\text { Guru memberi kesempatan pada siswa untuk } \\
\text { mempresentasikan hasil diskusinya dan } \\
\text { membantu dalam kegiatan tukar pendapat }\end{array}$ \\
\hline 5 & $\begin{array}{l}\text { Melakukan analisis dan evaluasi terhadap } \\
\text { proses pemecahan masalah }\end{array}$ & $\begin{array}{l}\text { Guru membantu siswa melakukan analisis dan } \\
\text { evaluasi terhadap proses berpikir mereka dalam } \\
\text { investigasi dan keterampilan intelektual yang } \\
\text { digunakan saat pemecahan masalah dan } \\
\text { merefleksi pembelajaran yang telah dilakukan }\end{array}$ \\
\hline
\end{tabular}

NCTM (2000) menyatakan bahwa pemecahan masalah adalah membangun pengetahuan matematika sebagai sarana siswa mengembangkan ide-ide matematika. Berbagai kurikulum di dunia memposisikan peran pemecahan masalah yang berbeda-beda. Kurikulum Finlandia memposisikan pemecahan masalah sebagai alat, sarana dan proses. Sebagai alat berfungsi untuk meningkatkan kemampuan berpikir siswa, sebagai sarana berfungsi untuk aktivitas pemecahan masalah dan sebagai proses berfungsi untuk menghubungkan informasi yang sudah diperoleh kemudian diaplikasikan terhadap situasi baru. Kurikulum Australia menempatkan pemecahan masalah sebagai kemampuan atau keterampilan untuk penyelidikan terhadap situasi masalah, merumuskan model penyelesaian, memilih strategi penyelesaian yang tepat dan mengkomunikasikan solusi yang efektif. Kurikulum Inggris memposisikan pemecahan masalah sebagai jantungnya matematika. Kurikulum Belanda memposisikan pemecahan masalah dalam proses pembelajaran sebagai sebuah pendekatan pembelajaran, yang selanjutnya populer dengan nama Realistic Mathematics Education. Kurikulum Hongkong memposisikan pemecahan masalah sebagai alat, sehingga untuk mengembangkan kemampuan siswa dalam proses pembelajaran menggunakan pendekatan pemecahan masalah. (Amam, 2017).

Perlu adanya modifikasi dalam menyelesaikan masalah dalam model pembelajaran berbasis masalah. Menurut Pressley (Riedesel, 1996) menyatakan bahwa siswa dikategorikan sebagai pemecah masalah yang baik dalam matematika apabila siswa tersebut memiliki pengetahuan mengenai berbagai strategi penyelesaian serta mampu untuk menggunakannya dalam proses perhitungan dengan tepat. Kemampuan tersebut muncul apabila siswa memiliki kesadaran berpikir, sehingga dapat menuntun melakukan tugas-tugas khusus, dan mengontrol apa yang akan dikerjakan (Zakiah, 2017b). Jika hal tersebut telah dimiliki oleh siswa secara sadar, tentu mampu mendapat hasil belajar maksimal. Hal yang bisa dilakukan adalah menyelesaikan masalah menggunakan langkah-langah penyelesaian Polya. Saat siswa melakukan investigasi dan menemukan solusi sendiri, siswa dibantu dengan langkah-langkah pemecahan masalah Polya (1973), yang terdiri: (1) memahami masalah; siswa mengidentifikasi informasi yang terdapat dalam soal dan yang ditanyakan; (2) menyusun rencana; siswa menghubungkan pengetahuan yang dimiliki sebelumnya dengan informasi yang terdapat dalam soal dan yang ditanyakan dalam soal; (3) melaksanakan rencana; siswa melakukan penghitungan/komputasi; dan (4) mengecek kembali; siswa melakukan koreksi ulang tentang menyelesaikan masalah yang diperoleh. 


\section{METODE PENELITIAN}

Penelitian ini merupakan kajian studi literatur. Penelitian ini merupakan jenis penelitian yang mencoba mengumpulkan data dari berbagai literatur. Penelitian dilakukan dengan mengamati dan mengkoneksikan berbagai komponen antara pendekatan kontekstual dengan karakteristik yang dimiliki oleh model pembelajaran berbasis masalah (problem based learning) berdasarkan langkahlangkah Polya. Penelitian ini termasuk kedalam literatur kepustakaan dengan alat pengumpul data yang digunakan adalah dokumentasi. Peneliti mengumpulkan data dari berbagai sumber yang relevan dengan topik penelitian, diantaranya dokumen terkait kebijakan pendidikan serta hasil penelitian yang sama oleh peneliti sebelumnya. Selanjutnya menambahkan data pendukung berupa jurnal, hasil penelitian, buku dan internet. Data yang telah dikumpulkan kemudian dilakukan analisis menggunakan metode deskriptif agar tergambarkan permasalahan yang sedang diteliti. Setelah data dikumpulkan dan dipelajari, dilanjutkan dengan pengolahan data. Analisis data dilakukan dengan menggunakan analisis deskriptif. Upaya ini dilakukan untuk memperoleh desain pembelajaran dengan pendekatan kontekstual menggunakan model pembelajaran berbasis masalah berbantuan langkah-langkah Polya.

\section{HASIL DAN PEMBAHASAN}

Inovasi pembelajaran yang dilakukan perlu memperhatikan prinsip-prinsip pembelajaran menurut standar proses (Permendikbud, 2016c), diantaranya:

1. Peserta didik mencari informasi secara mandiri;

2. Pembelajaran menggunakan beragam sumber belajar;

3. Pembelajaran menggunakan pendekatan ilmiah;

4. Rancangan pembelajaran berbasis kompetensi;

5. Menggunakan desain pembelajaran terpadu;

6. Membuat soal dengan menyediakan jawaban yang memiliki kebenarannya multi dimensi;

7. Merancang pembelajaran mengembangkan keterampilan aplikatif;

8. Meningkatkan hard skills dan soft skills;

9. Memfasilitasi peserta didik menjadi pembelajar sepanjang hayat;

10. Memberi contoh keteladanan, membangun motivasi, dan mengembangkan daya kreativitas;

11. Pembelajaran dilaksanakan tidak hanya di sekolah, tetapi juga di rumah dan di masyarakat;

12. Menggunakan teknologi informasi dan komunikasi dalam proses pembelajaran; dan

Tujuan dari pelaksanaan pembelajaran pada setiap satuan pendidikan untuk mengembangkan kompetensi siswa pada ranah sikap, pengetahuan, dan keterampilan. Ketiga ranah kompetensi tersebut masing-masing memiliki perbedaan dalam proses memperolehnya. Pada ranah sikap dapat dikembangkan melalui kegiatan, meliputi: menerima, menjalankan, menghargai, menghayati, dan mengamalkan. Pada ranah pengetahuan dapat dikembangkan melalui kegiatan, meliputi: mengetahui, memahami, menerapkan, menganalisis, mengevaluasi, dan mencipta. Sedangkan pada ranah keterampilan dapat dikembangkan melalui kegiatan, meliputi: mengamati, menanya, mencoba, menalar, menyaji, dan mencipta.

Pada tingkat satuan pendidikan jejang SMA/MA/SMALB/SMK/MAK/Paket C/Paket C Kejuruan memiliki karakteristik proses pembelajaran berbasis mata pelajaran. Pelaksanaan kegiatan pembelajaran secara keseluruhan difokuskan pada pengembangan ketiga ranah tersebut. Hal ini mengindikasikan bahwa apabila guru mampu merancang kegiatan pembelajaran mengikuti prinsipprinsip pembelajaran di atas, maka akan mencetak siswa yang memiliki kualitas pribadi meliputi sikap, pengetahuan, dan keterampilan yang baik.

Karakteristik pembelajaran menggunakan PBM, diantaranya: (1) menggunakan kegiatan kolaboratif, ini menjadikan siswa sebagai self-directed problem solver; (2) melakukan kegiatan perencanaan, memotivasi siswa untuk membuat prediksi dan menemukan solusi penyelesaian; dan (3) memfasilitasi siswa untuk memilih berbagai strategi penyelesaian, serta menghimpun dan 
mengkomunikasikan gagasan; (4) melatih siswa untuk mampu mempresentasikan hasil karya; dan (5) membiasakan siswa untuk melakukan perenungan kembali terhadap proses berpikir mereka dalam menyelesaikan masalah.

Pemilihan tipe masalah dalam menerapkan PBM akan mempengaruhi kesuksesan dalam pembelajaran. Menurut Herman (2007) menyatakan bahwa tipe masalah yang dapat diterapkan dalam pembelajaran menggunakan PBM meliputi masalah terbuka (open-ended problem atau illstructured problem) dan masalah terstruktur (well-structured problem). Dalam hal ini, apabila guru merancang masalah menggunakan jenis masalah terstruktur, maka untuk menjawab permasalahan tersebut siswa perlu melakukan beberapa tahap penyelesaian dengan menggunakan subsubmaslah dan penyimpulan. Sedangkan untuk merancang masalah terbuka, guru perlu memfasilitasi jawaban siswa yang memiliki banyak alternatif penyelesaian namun memiliki satu jawaban benar atau multijawaban yang benar.

Rancangan implementasi pendekatan kontekstual menggunakan model pembelajaran berbasis masalah berbantuan langkah-langkah Polya disajikan pada tabel berikut.

\section{Tabel 2. Desain pembelajaran menggunakan pendekatan kontekstual pada model pembelajaran berbasis masalah berdasarkan langkah-langkah Polya}

\begin{tabular}{|c|c|}
\hline Fase/Sintaks & Kegiatan Pembelajaran \\
\hline $\begin{array}{l}\text { Mengorientasikan siswa } \\
\text { pada masalah }\end{array}$ & $\begin{array}{l}\text { a) Guru membagi peserta kedalam kelompok-kelompok dengan setiap } \\
\text { kelompok terdiri dari peserta didik dengan kemampuan yang } \\
\text { heterogen. } \\
\text { b) Guru membagikan bahan ajar kepada setiap kelompok. }\end{array}$ \\
\hline $\begin{array}{l}\text { Mengorganisasikan } \\
\text { kegiatan pembelajaran }\end{array}$ & $\begin{array}{l}\text { a) Peserta didik dalam kelompoknya mengidentifikasi masalah } \\
\text { kontekstual yang terdapat dalam bahan ajar. } \\
\text { b) Peserta didik dalam kelompoknya berupaya mengumpulkan berbagai } \\
\text { sumber yang berhubungan dengan permasalahan yang terdapat } \\
\text { dalam bahan ajar. }\end{array}$ \\
\hline $\begin{array}{l}\text { Membimbing invesitigasi } \\
\text { mandiri dan kelompok } \\
\text { berbantuan langkah- } \\
\text { langkah pemecahan } \\
\text { masalah Polya }\end{array}$ & $\begin{array}{l}\text { a) Peserta didik berdiskusi dalam kelompok menyelidiki permasalahan } \\
\text { yang terdapat dalam bahan ajar (tahap memahami masalah). } \\
\text { b) Peserta didik dalam kelompoknya saling bertukar ide terkait } \\
\text { penyelesaian masalah yang ada dalam bahan ajar (tahap rencana } \\
\text { penyelesaian dan menyelesaikan masalah). } \\
\text { c) Apabila ada hal-hal yang sulit dipahami setelah didiskusikan bersama, } \\
\text { peserta didik boleh bertanya kepada guru (tahap mengecek kembali). } \\
\text { d) Guru tidak memberikan jawaban secara langsung melainkan melalui } \\
\text { scaffolding untuk memancing kreativitas siswa. }\end{array}$ \\
\hline $\begin{array}{l}\text { Melakukan pengembangan } \\
\text { dan mempresentasikan } \\
\text { hasil karya }\end{array}$ & $\begin{array}{l}\text { a) Peserta didik dalam kelompoknya menuliskan jawaban dalam kertas } \\
\text { yang disediakan. } \\
\text { b) Beberapa kelompok yang dipilih secara acak mempresentasikan hasil } \\
\text { diskusi. } \\
\text { c) Peserta didik bersama-sama guru memberikan komentar terhadap } \\
\text { hasil kelompok yang mempresentasikan hasil pekerjaannya. } \\
\text { d) Guru bersama-sama peserta didik memberikan pembenaran konsep } \\
\text { apabila terdapat kekeliruan } \\
\text { e) Peserta didik dan guru bersama-sama menyimpulkan konsep yang } \\
\text { didiskusikan. } \\
\text { f) Guru memberikan reward pada kelompok dengan penyajian terbaik. }\end{array}$ \\
\hline $\begin{array}{l}\text { Melakukan analisis dan } \\
\text { evaluasi terhadap proses } \\
\text { pemecahan masalah }\end{array}$ & $\begin{array}{l}\text { a) Peserta didik mengerjakan LAS terkait materi yang sudah dipelajari. } \\
\text { b) Beberapa orang peserta didik menuliskan hasil temuannya di papan } \\
\text { tulis. }\end{array}$ \\
\hline
\end{tabular}


Fase/Sintaks

\section{Kegiatan Pembelajaran}

c) Guru bersama-sama peserta didik membahas pekerjaan yang tertulis di papan tulis.

d) Guru memberikan umpan balik serta penguatan kepada seluruh peserta didik terhadap tanggapan peserta didik terkait materi yang telah dipelajari.

Pada tiap fase pemecahan masalah dalam pembelajaran menggunakan PBM melalui kegiatan berikut: siswa memahami masalah (understanding the problem). Pada langkah pertama ini guru memberikan pertanyaan kepada siswa diantaranya adalah: (1) apakah yang tidak diketahui?; (2) data apa yang diberikan?; (3) apakah kondisi/informasi yang tersedia memenuhi untuk mencari penyelesaian yang ditanyakan?. Kemudian siswa diminta untuk mengidentifikasi data berdasarkan informasi yang terdapat pada masalah yang diberikan.

Langkah kedua dalam menyelesaikan masalah yaitu membuat rencana untuk penyelesaian masalah (devising a plan). Pada langkah kedua ini guru memberikan pertanyaan kepada siswa diantaranya adalah: (1) teori mana yang dapat digunakan dalam menyelesaikan masalah ini?; (2) perhatikan apa yang ditanyakan?; (3) dapatkah hasil dan metode yang pernah dilakukan sebelumnya bisa digunakan untuk menyelesaikan permasalahan saat ini?; (4) apakah semua data yang ada sudah digunakan?; (5) sudahkah dipertimbangkan ide-ide penting yang akan digunakan dalam soal tersebut?. Pada langkah ini guru membimbing dan mengarahkan siswa untuk mampu membuat perencanaan berdasarkan hasil identifikasi data pada langkah pertama.

Langkah ketiga dalam menyelesaikan masalah yaitu melakukan perhitungan/komputasi (carrying out the plan). Kesuksesan pada langkah ini tergantung pada keberhasilan pada tahap perencanaan penyelesaian. Prosedur yang ditempuh adalah: (1) memeriksa penyelesaian pada setiap langkah apakah sudah sesuai atau belum?; (2) bagaimana membuktikan bahwa langkah penyelesaian yang digunaan sudah benar?. Pada langkah ini guru membimbing dan mengarahkan siswa untuk mampu melakukan perhitungan (komputasi) berdasarkan hasil rencana penyelesaian pada langkah kedua. Siswa yang mampu membuat rencana penyelesaian/memilih strategi penyelesaian yang benar akan mampu melakukan perhitungan dengan tepat.

Selanjutnya pada langkah terakhir, yaitu mengecek kembali (looking back). Polya menekankan pada memeriksa kebenaran jawaban berdasarkan proses dan hasil. Pada langkah ini guru membimbing siswa melalui pertanyaan diantaranya adalah: (1) dapatkah diperiksa sanggahannya?; (2) adakah cara yang lain?. Setelah siswa mampu melaksanakan perhitungan dengan tepat, selanjutnya siswa harus melakukan pengecekan ulang terhadap langkah-langkah penyelesaian yang telah dilakukan.

Dengan demikian, hasil kajian dalam penelitian ini menunjukkan bahwa rancangan desain pembelajaran dengan pendekatan kontekstual menggunakan model pembelajaran berbasis masalah berbantuan langkah-langkah Polya merupakan salah satu inovasi pembelajaran matematika yang berlandaskan bahwa siswa mengkonstrusi pengetahuannya sendiri. Menurut paham dari aliran konstruktivisme, bahwa ketika individu diberi informasi yang baru, maka dia akan mengolah informasi tersebut berdasarkan pengetahuan yang telah dimiliki sebelumnya dan pengalaman baru pribadi tersebut.

Teori pengkonstruksian pengetahuan yang dikemukakan Vygotsky (Herman, 2007) terdiri dari tiga tahapan: (1) tahap perkembangan aktual, terjadi pada saat siswa diberikan permasalahan yang menantang sehingga akan terjadi konflik kognitif di dalam dirinya. Oleh karena itu siswa akan menggunakan pengetahuan yang telah dimiliki sebelumnya untuk menyelesaikan masalah tersebut; (2) tahap perkembangan potensial, terjadi ketika siswa berinteraksi dengan pihak yang memiliki kemampuan lebih darinya, misalkan teman, guru atau orangtua. Perkembangan potensial ini akan mencapai tahap maksimal jika pembelajaran dilakukan secara kooperatif (cooperative learning). 
Dalam hal ini, guru memiliki peran sebagai fasilitator dengan menerapkan teknik scaffolding, yaitu membantu kelompok siswa menggunakan teknik bertanya dan teknik probing, atau memberikan petunjuk seperlunya. Pada tahap ini, struktur kognitif siswa akan membentuk skema baru yang lebih lengkap; (3) tahap internalisasi, ini merupakan aktivitas berpikir tingkat tinggi. Hal ini terjadi berasal dari interaksi sosial. Menurut teori perkembangan mental berdasarkan teori Piaget, bahwa proses pada tahapan internalisasi akan terjadi penyeimbangan struktur-struktur internal berdasarkan masukan-masukan eksternal. Pada tahap ini, agar terjadi keseimbangan (equilibrium) pada diri siswa maka perlu adanya intervensi dari guru atau yang lainnya sehingga pada proses asimilasi dan akomodasi dapat berlangsung dengan baik.

Lebih lanjut, hasil penelitian yang telah dilakukan Herman (2007), menunjukkan bahwa pembelajaran melalui pemberian masalah terbuka dan masalah terstruktur mampu meningkatkan kemampuan berpikir matematis tingkat tinggi, ditinjau dari perbedaan sekolah, kemampuan matematika, ataupun gender. Oleh karena itu, PBM dapat diterapkan di lapangan dalam proses pembelajaran matematika.

\section{KESIMPULAN}

Pembelajaran yang efektif dapat diwujudkan, salah satunya saat guru menyusun rencana pembelajaran dengan pemilihan model pembelajaran. Kemampuan guru untuk memilih model pembelajaran dengan memperhatikan karakteristik materi pelajaran, ketersediaan media pembelajaran, perkembangan mental dan fisik siswa. Perlu adanya modifikasi dalam menyelesaikan masalah pada pembelajaran menggunakan pendekatan kontekstual pada model pembelajaran berbasis masalah. Hal yang dilakukan adalah pada tahap menyelesaikan masalah menggunakan bantuan langkah-langah penyelesaian Polya. Inovasi pembelajaran yang dilakukan pada penelitian ini adalah mengkoneksikan materi pelajaran dengan konteks dunia nyata melalui pembelajaran menggunakan pendekatan kontekstual pada model pembelajaran berbasis masalah berdasarkan langkah-langkah Polya. Desain pembelajaran menggunakan pendekatan kontekstual pada model pembelajaran berbasis masalah berdasarkan langkah-langkah Polya, yaitu: (1) mengorientasikan siswa pada masalah; (2) mengorganisasikan kegiatan pembelajaran; (3) membimbing invesitigasi mandiri dan kelompok berdasarkan langkah-langkah pemecahan masalah Polya, diantaranya: (a) memahami masalah; (b) menyusun rencana; (c)melaksanakan rencana; dan (d) mengecek kembali; (4) melakukan pengembangan dan mempresentasikan hasil karya; dan (5) melakukan analisis dan evaluasi terhadap proses pemecahan masalah.

\section{REKOMENDASI}

Dengan memperhatikan hasil penelitian dan kesimpulan yang telah dikemukakan, peneliti menyarankan agar hasil dari penelitian ini dapat dikembangkan oleh peneliti selanjutnya untuk diterapkan sebagai salah satu usaha meningkatkan kemampuan matematis siswa. Selain itu untuk peneliti selanjutnya dapat menciptakan inovasi-inovasi lain pada model pembelajaran lain yang sesuai dengan kurikulum yang berlaku. Sehingga akan meningkatkan kualitas pendidikan termasuk kemampuan matematis siswa.

\section{UCAPAN TERIMAKASIH}

Penelitian ini merupakan hibah Penelitian Dosen Pemula. Penulis menyampaikan ucapan terima kasih kepada pihak Direktorat Riset dan Pengabdian kepada Masyarakat, Kementerian Riset, Teknologi, dan Pendidikan Tinggi yang telah membiayai penelitian ini.

\section{DAFTAR PUSTAKA}

Amam, A. (2017). Penilaian kemampuan pemecahan masalah matematis siswa SMP. Teorema: Teori dan Riset Matematika 2(1), 39-46. 
Arends, R. I. (2012). Learning to Teach (Ninth Edition). New York: McGraw-Hill.

Depdiknas. (2002). Pembelajaran dan Pengajaran Kontekstual. Jakarta: Depdiknas.

Fatimah, A. T. \& Zakiah, N. E. (2018). Kelancaran Prosedural Matematis Dalam Pemecahan Masalah Konteks Pemasaran. Mathline Jurnal Matematika dan Pendidikan Matematika, 3(2), 141-150.

Herman, T. (2007). Pembelajaran berbasis masalah untuk meningkatkan kemampuan berpikir matematis tingkat tinggi siswa sekolah menengah pertama. Educationist, 1(1), 47-56.

Jumadi. (2003). Pembelajaran Kontekstual dan Implementasinya. Makalah disampaikan pada Workshop Sosialisasi dan Implementasi Kurikulum 2004 Madrasah Aliyah DIY, Jateng, Kalsel di FMIPA UNY.

National Council of Teachers of Mathematics (NCTM). (2009). Principles and Standards for School Mathematics. Reston, VA: NCTM.

Permendikbud (2016a). Peraturan Menteri Pendidikan dan Kebudayaan Nomor 20 Tahun 2016 Tentang Standar Kompetensi Lulusan Pendidikan Dasar dan Menengah. Jakarta.

Permendikbud (2016b). Peraturan Menteri Pendidikan dan Kebudayaan Nomor 21 Tahun 2016 Tentang Standar Isi Pendidikan Dasar dan Menengah. Jakarta.

Permendikbud (2016c). Peraturan Menteri Pendidikan dan Kebudayaan Nomor 22 Tahun 2016 Tentang Standar Proses Pendidikan Dasar dan Menengah. Jakarta.

Polya, G. (1973). How to Solve It (Second Edition). United States of America: Princeton University Press.

Riedesel, C. A., Schwarts, J. E., dan Clements, D. H. (1996). Teaching Elementary School Mathematics. Boston: Allyn and Bacon.

Silver, E. A. (1997). Fostering Creativity through Instruction Rich in Mathematical Problem Solving and Problem Posing. [Online]. Tersedia: http://www.fizkarlsruhe.de/fiz/publications/zdm/2dm97343.pdf.

So, H.J., Kim, B. (2009). Learning about problem based learning: Student teachers integrating technology, pedagogy and content knowledge. Australasian Journal of Educational Technology, 25(1), 101-116.

Sunaryo \& Fatimah. 2018. Implementasi pendekatan kontekstual pada model pembelajaran scaffolding untuk meningkatkan kemampuan berpikir kritis matematik siswa. Laporan hasil penelitian: Pendidikan Matematika, FKIP, Universitas Galuh.

Zakiah, N. E. (2017a). Pembelajaran dengan pendekatan kontekstual berbasis gaya kognitif untuk meningkatkan kemampuan metakognitif siswa. Pedagogy 2(2), 11-29. https://journal.uncp.ac.id/index.php/Pedagogy/article/view/700 
•120 Teorema: Teori dan Riset Matematika, 4(2), 111-120, September 2019

Zakiah, N. E. (2017b). Pembelajaran dengan pendekatan kontekstual berbasis gaya kognitif untuk meningkatkan self awareness siswa. Teorema: Teori dan Riset Matematika 2(1), 11-20. http://dx.doi.org/10.25157/teorema.v2i1

Zakiah dan Sunaryo. 2017. Pembelajaran dengan pendekatan kontekstual berbasis gaya kognitif untuk meningkatkan kemampuan metakognitif dan self awareness siswa. Laporan hasil penelitian: Pendidikan Matematika, FKIP, Universitas Galuh. 